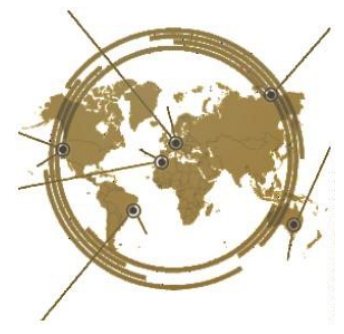

OPEN ACCESS

ISSN 25033492 (online) ${ }^{*}$ Correspondence:

Damar Isti Pratiwi

damar@ppi.ac.id

Received: 21st January 2021 Accepted: 14th April 2021 Published: 16th April 2021

Citation:

Damar Isti Pratiwi, Dadang Sanjaya Atmaja, Henry Widya Prasetya

(2021). Multiple e-learning tehnologies on practicing TOEFL struture and written expression.

J.Eng.Educ. Society. 6:1. doi: $10.21070 /$ jees.v6i1.1194

\section{Multiple e-learning technologies on practicing TOEFL structure and written expression}

\author{
Damar Isti Pratiwi*, Dadang Sanjaya Atmaja, Henry Widya Prasetya \\ Politeknik Perkeretaapian Indonesia, Indonesia
}

The present study investigates how to implement multiple e-learning technologies on practicing TOEFL PBT Section 2, Structure and Written Expression, and its effectiveness. It is a case study at Indonesian Railway Polytechnic. The participants were 48 students of the Railway Mechanical Technology program observed during eight online TOEFL practicing classes. The data were collected using observation note to describe the implementation of e-learning technologies, comparing each score to determine the effectiveness of the technologies and a questionnaire to identify students' feedback. The findings identified how to implement multiple e-learning technologies on practicing TOEFL PBT Section 2 in which effective to increase students' TOEFL score; those technologies were regarded as interesting media on practicing TOEFL Structure and Written Expression and received more positive feedbacks than the drawback from the students of Railway Mechanical Technology program. These imply that implementing multiple e-learning technologies on practicing TOEFL Structure and Written Expression enhances students' learning outcomes.

Keywords: e-learning, quizizz, socrative, Kahoot!, Google Form, TOEFL structure

\section{INTRODUCTION}

The vision of Indonesian Railway Polytechnic is to generate competence and professional human resources in railway transportation based on Railway Act No 23/2007. One of the competences is mastering one foreign language as English is chosen as it is the most widely language spoken in the world. In addition, in industrial revolution 4.0,the university student needs to be able to successfully participate in rapidly globalizing world (Pratiwi et al., 2016) as mastering English will be a passport for someone to enter the global world and to compete with others in a global level (Rokhyati, 2013). It is suggested that Standard English has to be taught in class, so the English proficiency also needs to be proven by English standardized tests, such as TOEFL, IELTS or TOEIC. In this case, Indonesian Railway Polytechnic has decided to use TOEFL PBT as the English standard proficiency measurement as it is instructed by the Human Resources Department of the Ministry of Transportation. Furthermore, this is appropriate as TOEFL is designed to measure the English proficiency of people whose native language is not English (ETS, 2017).

TOEFL gives students the opportunity to prove they can communicate ideas effectively by simulating university classroom and student life communication (Mufidah, 2012). Several universities determine TOEFL score as the graduation standard requirement in Indonesia (Tilana et al., 2019), including Indonesian Railway Polytechnic. It has been set that the minimum TOEFL score is 480 for all students as a graduation requirement; therefore, students need to practice TOEFL whether in class or outside the classroom as many as students find it difficult to do TOEFL. In addition, one big common problem 
for students of TOEFL is section 2, structure and written expression, and students often feel stressed with This part (ETS, 2017). In other cases, students regarded structure and written expression as the most challenging part of TOEFL (Hajri et al., 2015; Thu, 2019). Accordingly, this study focuses on TOEFL section 2, structure and written expression.

Language teaching has been extensively influenced by the innovations made in science and technology (Poudel, 2015) as technology advancement has supported rapid global society growth of social interaction. Learners may need to change their learning skills and approach to what is most appropriate and use technological devices for efficient learning (Kaya \& Balta, 2016) while teachers have to generate their learning to be more customized, hyper, intelligent, portable, worldwide and virtual (Sariani et al., 2020). When effectively used, ICT tools can enhance the learning process and supporting collaborative works to facilitating authentic assessment (Waluyo, 2020). Encountering students with an online venue can help them foster their language learning and provide an empowering means for achieving educational goals. In short, practicing TOEFL PBT, especially in Section 2, needs to use effective test preparation techniques to derive optimum result (Manoj \& Hijazi, 2018).

Mobile applications for language learning purposes are available. Yet, there seems to be a lack of variety in applications for using them in class (Yoon, 2017), so teachers need to get effective and efficient teaching and learning applications. In this technological age, integrating multimedia technology and traditional teaching methods is considered a key promoter of creating an effective learning atmosphere across the globe(Mallick et al., 2020). On the other hand, teaching using traditional methods only could cause passiveness and boredom amongst students(Ubaedillah et al., 2020). Recently, many researchers have focused on using Student Response Systems (SRS) that is reported positive experiences in the classroom which increase student engagement, participation and outcome (Azmi, 2017; Benson et al., 2016; Heaslip et al., 2014). These have offered teachers intelligent tools to enable students to adapt them to suit their learning need. In this current study, the use of SRS is implied in practicing TOEFL Structure and Written Expression, not only general English.

Multiple e-learning technologies offered in this study are about using SRS in the online class. There are Quizizz, Socrative, Kahoot! and Google Form to practice TOEFL structure and written expression. These approaches are quite new for Railway Mechanical Technology students. Only a few lecturers implemented these technologies; however, in this pandemic era, the online teaching and learning process is mandatory (Stickler et al., 2020). It is hoped that by implementing multiple e-learning technologies, students could be motivated to practice TOEFL, especially Section 2, to achieve scores as required by the campus. Thus, this study has the following research questions:
1. How to implement multiple e-learning technologies on practicing TOEFL Structure and Written Expression?

2. Are the technologies effective as media in practicing TOEFL Structure and Written Expression?

3. How are the students' feedbacks on practicing TOEFL Structure and Written Expression?

\section{Quizizz}

Quizizz is a gamified online tool which helps students check their knowledge and progress in learning (Rahayu \& Purnawarman, 2019). It assists the students' mastery of English by multiplayer classroom activity, allowing all students to practice English together using their mobile phones(Rahayu \& Purnawarman, 2019). This platform also allows the students to see the questions and all possible answers on their own devices shuffled for each student to keep focusing on doing their own work (Basuki \& Hidayati, 2019). Many studies have identified this feature as a positive reinforcement to students and entertaining them during the teaching and learning process (Mohamad et al., 2020; Poudel, 2015; Yanmei et al., 2018)).

This platform has two kinds of activities: live quiz and homework, making teachers more flexible to use the application, whether online or offline. Besides, it provides a leaderboard as one of its unique characteristics, instead of memes and timer. The leader board shows the performance level and students' achievement, motivating the students and creating healthy competition (Mohamad et al., 2020). For teachers, the activity reports are available so that the students' progress could be monitored easily and instantly as soon as the activity finished. Nonetheless, this platform required a stable data connection to be accessed due to its interactive leader board and memes. In some areas that are not covered with good signal, this application takes a long time to connect. This platform also has letter limitations on questions (300) and answers (100) sections that could not be used for practicing more extended questions.

\section{Socrative}

Socrative was developed in 2010 by Boston-based graduate students for response formative assessment(Shaban, 2017). This application provides activities which engage students with three types of choices: launch a quiz, receive exit tickets and ask a quick question for instant feedback that could be formed in three question models: multiple-choice, true-false and short answer. Besides, teachers could personalize activities based on the classroom's need; they also could adjust teaching and learning activities based on the students' results as those are instantly available when the activities finished. Furthermore, this platform is easy to create, and the automatic grading makes teachers save their time, so it is more time to catering the classroom's need.

Many researchers have implemented Socrative as multimedia in teaching the learning process in their classroom, which empowers teachers to engage their classrooms and motivate their students to be taught (Kaya \& Balta, 2016). This also enhances students' performance as students improve their learning experience (Dakka, 2015) and is proven to be effective multimedia to teach grammar (Maesaroh et al., 2020). Additionally, it contributes to promote students' critical thinking and stimulate students' collaboration (Shaban, 2017). In short, 
Socrative provides positive vibration on students' attitude towards learning a language (Mohammed \& Chouthaiwale, 2018), and that means that it provides authenticity by which learners interact easily with others all over the world.

\section{Kahoot!}

Kahoot! was formally launched in August 2013 by building on Dr Alf Inge Wang and his students, Morten Versik, research' on lecture quiz (Chiang, 2020). As the tagline on its website, "make learning awesome, Kahoot! engages learners through games which could unlock the learning potential of each learner. Moreover, it is stated that Kahoot!'s principle is creating a game-based platform for students to enjoy learning in a fun, interactive and competitive manner. Accordingly, this application provides three types of activities; quiz, discussion and survey, which could be played by the whole class lively or as homework via technological devices such as smart phone or computer.

This application has brought many beneficial values for teachers and students. It receives a positive attitude from EFL students in the class (Chiang, 2020), which could make students collaborate as well as compete through interactive games (Basuki \& Hidayati, 2019), improves students' English score, enhances students' motivation for coming in class, and is proven to be effective as multimedia to teach grammar (Maesaroh et al., 2020). This also allows teachers to evaluate the students' results effectively and efficiently as the results are recorded and easily tracked. Teachers could make use Kahoot! provided on the application made by public users or modifies the provided activity, instead of creating their own based on their classrooms' needs. Its flexibility, for instance, makes teachers have more choices in conducting the teaching and learning process. However, just like in the Quizizz platform, letter limitations on questions (300) and answers (100) make this application not to write more extended questions. Also, this platform could be a problem when access to the internet, computer or mobile phone is limited.

\section{Google Form}

Google form is a web-based application used to create forms for data collection purposes, such as surveys, quizzes or event registration sheets (Sivakumar, 2019). The form can be shared by sending the link via email, message or other social media platforms, and it is free so that this platform is efficient to be used. The data gathered is in the form of a spreadsheet recorded automatically as the respondents fill the form. Teachers could use this form to conduct a test in multiple-choice, short answer or paragraph during the teaching and learning process. In creating a quiz, teachers could use multiple-choice and divine specific point for each number so that the result and the point would be automatically recorded when students finish the test.

This platform receives positive feedback from students and is proven to be effective media in conducting the test (Sepyanda, 2018). The results generated are secure as the diagram in the spreadsheet cannot be edited. The spreadsheet containing the respondents' data can be modified, but the diagram only shows the actual data. Furthermore, the forms allow teachers to collect students' email address and limit the answer by managing the quiz setting, and the look of the forms could be checked before sending to the respondents. Nevertheless, this form has limited design customization, and its responsiveness could not be gathered automatically after the students finish filling-up the form. It cannot be integrated and connected with large datasets, and a particular limitation regarding its capabilities to accept text (up to $500 \mathrm{~Kb}$ ) and images (up to $2 \mathrm{Mb}$ ).

\section{TOEFL Structure and Written Expression}

The test is a necessary process to measure learning achievement (Rahmawati et al., 2019). TOEFL is a standardized test widely used across more than one hundred countries since its initial establishment in the early 1960s. It has been developed to measure the English proficiency of non-native speakers both in educational institutions and non-educational agencies for many purposes, such as school admission, graduation requirement, and working recruitment. There are three types of TOEFL; those are Paper-Based TOEFL (PBT), the Computer-Based TOEFL (CBT) and the Internet-Based TOEFL (IBT). TOEFL PBT and $\mathrm{CBT}$ are tested listening, structure and written expression, reading and writing, while IBT is tested reading, listening, speaking and writing. Specifically, in TOEFL PBT Section 2, structure and written expression, there are two types of questions: incomplete sentence and sentence correction (Tilana et al., 2019).

There are 40 questions in TOEFL PBT structure and written expression divided into two parts, completing sentences for 15 questions and the rest 25 questions for error analysis. The test takers only have 25 minutes to finish this part. Regarding the limited time and the total questions of this part, many students face difficulties in doing the test $(\mathrm{Thu}, 2019)$. So, TOEFL is needed to practice more to make the students get used to the structure and written expression. There is ten main topics of this section (Hajri et al., 2015): (1) Subject-verb agreement; (2) Verb - tense agreement; (3) Word forms; (4) Reduced clauses; (5) Connectors; (6) Gerunds and Infinitive; (7) Comparisons; (8) Clause formation; (9) Parallel structure; (10) Redundancy.

\section{METHODS}

\section{Research Design}

This was an action case study in the Railway Mechanical Technology program of Indonesian Railway Polytechnic in terms of practicing TOEFL PBT Section 2, Structure and Written Expression implementing multiple e-learning technologies Quizizz, Kahoot!, Socrative and Google Form. As an action case study, whereas classroom practitioner investigated in his or her professional context, it concerned with chronological narrative events of the case and focused on the individual group to seek and understand their perceptions. Hence, this research involved 48 second-year students in the academic year $2020 / 2021$ as the sample, representing 144 students of the Railway Mechanical Technology program from all level; the first year, second year and third year. This sample was taken based on purposive sampling in which the first-year students were having online class at home, while the second and third-year students did their internship programs. 


\section{Data Collection and Analysis}

The boundaries for collecting data using a mixed-method research design in which qualitative and quantitative data are collected. The qualitative data gathered through observation, interview, questionnaire, documents, visual materials, and recorded information. While quantitative data collected through TOEFL PBT Section 2 results. The observation was used to describe the implementation of multiple e-learning technologies in practicing TOEFL PBT Structure and Written Expression. While TOEFL PBT Section 2 results were essential to know the effectiveness of implementing the application in the class, the questionnaire was for gathering students' feedback.

The observation result was analyzed by narrating the process of implementing multiple e-learning technologies. There were eight meetings in which each platform was used two times during this study. The results of TOEFL PBT Section 2 were counted using Hake's theory about normalized gain ( $\mathrm{N}$-gain) score by comparing the average score and maximum score of each application. The results were compared to determine the effectiveness of each platform for practicing TOEFL PBT Section 2 (Coletta \& Steinert, 2020). Manually, this could be counted and classified as follow:

Note:

$$
\mathrm{N} \text { gain score }=\frac{(\text { Spost })-(\text { Spre })}{(\text { Smax })-(\text { Spre })}
$$

Spost $=$ average posttest score

Spre $=$ average pretest score

Smax = maximum score

The questionnaire was in the form of an open-ended questionnaire. It was used to investigate students' feedback after practicing TOEFL PBT Section 2 using those multiple e-learning technologies: Quizizz, Kahoot!, Socrative and Google Form. Accordingly, students were also asked to number the multiple e-learning technologies used to practice TOEFL PBT Structure, and Written Expression started from their most favorite to the least. Students' perspective and feedback were essential to know the appropriate multimedia used in class based on learners' need.

The research's validity and reliability were fulfilled from triangulation in which qualitative data analysis involved simple quantitative analysis. Triangulation, at its simplest, combined two or more different data collections methods within one study. In this study, triangulation has been fulfilled by combining qualitative data collection and analysis through observation and questionnaire and quantitative data collection and analysis through comparing pretest and posttest TOEFL PBT Section 2 results using the normalized gain score.

\section{FINDINGS}

Implementing Multiple E-learning Technologies

There were eight meetings for practicing TOEFL PBT Structure, and Written Expression in this study conducted once a week. The test sources were taken from The Official Guide to the TOEFL $5^{\text {th }}$ Edition (ETS, 2017), which provided authentic TOEFL practice test, so there was no need of testing the reliability and validity of the practice test as this research used a standardized test from ETS. Before conducting the action case study, the teacher asked the participants to do the test on paper to get the pretest score. The participants were 48 students from the Railway Mechanical Technology program who joined the research during eight meetings altogether.

Before practicing with the students, teachers had to prepare all questions and correct each application's answer. For the Quizizz application, teachers were required to make an account or sign up using their Google account at www.quizizz.com. Then create a new quiz by adding the questions one by one and click its correct answer. As for TOEFL need, teachers must choose the multiple-choice question type. Furthermore, teachers had to decide the time for each question that was 37.5 second, as the maximum time for 40 numbers was 25 minutes. As for practicing utility, teachers could add explanations for each number that the students could read after finishing the quiz. This quiz could be set up as a one-time quiz or as homework that the students could practice many times in their spare time. Teachers just needed to click share quiz and shared the link to their assigned students for sharing the quiz. The teacher's code was needed when students wanted to do the quiz, so teachers had to share the code on their application. After finishing the quiz, the results could be downloaded through the Quizizz website or sent through a registered email used for signing up.

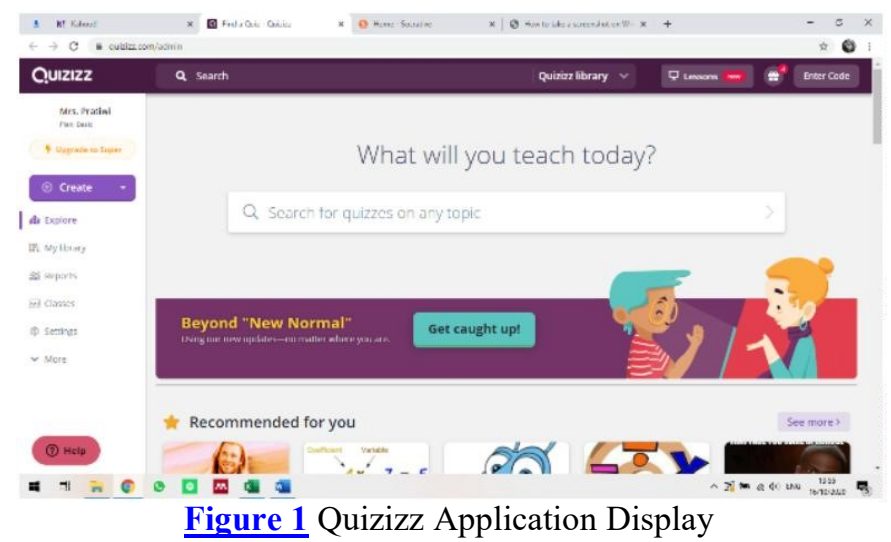

In the Socrative application, the first step was just like in Quizizz, in which the teachers had to create an account by signing up a new account or using their Google account in www.socrative.com. After that, in creating a new quiz, teachers must choose multiple-choice question types for TOEFL practice. Teachers could create a new quiz online through Socrative website or offline by downloading quiz templates and then uploading the fulfilled template on the Socrative website.

Unlike Quizizz, teachers did not need to decide the time for the quiz or each question as the time would be determined when teachers opened the quiz to be done. In conducting the quiz, teachers needed to ask their students to enter the Socrative website; then, they shared the teacher's code on their account. There were some additional features, such as jumbled the questions and answers so that each student would get different numbers or questions and randomized answer. After finishing the quiz, teachers could download the result thoroughly from the 
Socrative website, save it on Google drive, or email it. If teachers wanted to use this as homework, they could not check the students' time to do the test as teachers had to online during the students were doing the test.

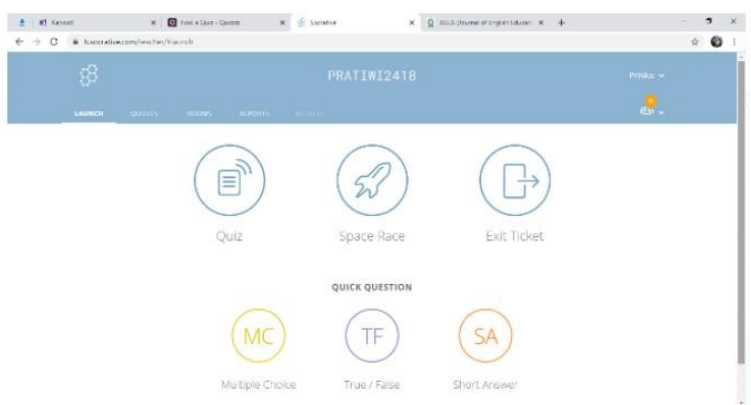

Figure 2 Socrative Application Display

Using Kahoot! application, teachers had to create an account in www.kahoot.com by entering details needed there or signing up using a Google account. For this research, the questions had to be set up in multiple-choice as this was about TOEFL Structure and Written Expression. Like the Quizizz application, the given time must be set up for each item, which was 37.5 seconds for each question, so the total time for 40 questions was 25 minutes. The correct answer and detail explanations of each question could be written below the question on the explanation column so that the students could learn more and automatically as often as possible during the activated time of the quiz. In this platform, teachers could set up a one-time quiz or as homework with decided time without online since the given time has been set up on each question. Using live game quiz, teachers just need to share the game pin to the students, while assigning the quiz as homework could be done by sharing the link of the quiz and the game pin so that the students could do the test as many as they wanted to practice in their available time. When the quiz finished, teachers downloaded the result through the application and sent it to email. There could be checked how many times each student did or practiced the quiz.

Google Form application is one platform from Google account that could be used as a quiz. The quiz could be created through logging in on Google Drive account then click new. There would be Google Form, which could be set up as a quiz by adding the correct answer, explanation, point and time given on each question so that by the time the quiz finished, the teachers could get the result. The students could get the correct answers and the explanation given. This could create autonomous learning for students

because the learners could learn in their own time. However, this application's display was just like a form without any additional memes' or pictures on the application. Unless this platform only recorded the submitted time, this could be set up if teachers wanted to collect students' email address to give feedback online by sending email to the students.

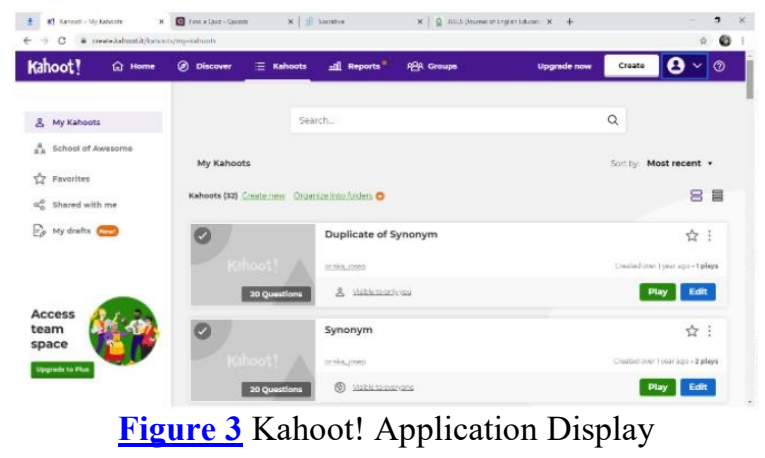

Google Form application is one platform from Google account that could be used as a quiz. The quiz could be created through logging in on Google Drive account then click new. There would be Google Form, which could be set up as a quiz by adding the correct answer, explanation, point and time given on each question so that by the time the quiz finished, the teachers could get the result. The students could get the correct answers and the explanation given. This could create autonomous learning for students because the learners could learn in their own time. However, this application's display was just like a form without any additional memes' or pictures on the application. Unless this platform only recorded the submitted time, this could be set up if teachers wanted to collect students' email address to give feedback online by sending email to the students.

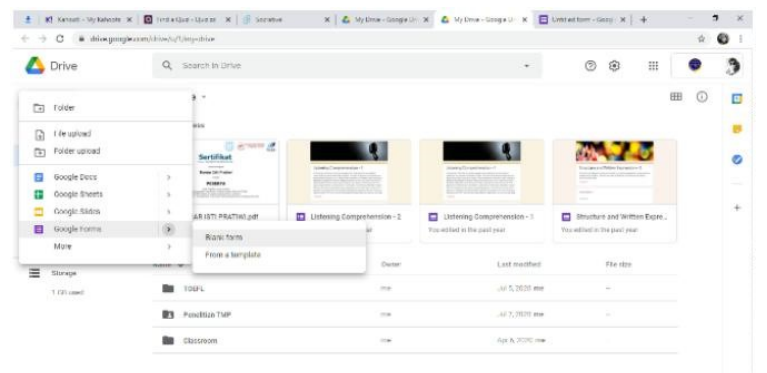

Figure 4 Google Form Application Display

Table 2 revealed the schedule of practicing TOEFL PBT Structure and Written Expression for Railway Mechanical Technology students.

The practicing test was started from the zoom meeting. The students must use a laptop or computer for doing the meeting. There the students were given guidelines in doing the test based on TOEFL guidelines written on the book. The next step was using a mobile phone for doing the test through a scheduled application. In doing this test, students must sit in front of the activated zoom meeting camera and be only given 25 minutes to do the application test. After 25 minutes, the application would automatically close. The activated zoom camera was functioned to check whether the students did the test by themselves or not, while the timekeeper was used to ensure that the students' time to do the test was as exact as TOEFL time.

\section{Test Results}

During eight TOEFL Structure and Written practice meetings using multiple e-learning technologies, each platform was used 
twice, so the Normalized gain score results were obtained two scores. Each score was compared with the pretest score, which has been done manually on paper before starting the research. The pretest average score result was 52. Table 3 below presented the average result of TOEFL Structure and Written Expression in each meeting using the different application as scheduled. The scores were then compared with the pretest score to get the Normalized Gain
Score of each application.

Table 1 N-Gain Score Category

\begin{tabular}{cc}
\hline \hline N Gain Score & Category \\
\hline $0.76-1.00$ & Very effective \\
$0.56-0.75$ & Effective \\
$0.41-0.55$ & Less effective \\
$0.01-0.40$ & Least effective \\
0.00 & Not effective at all \\
\hline
\end{tabular}

Table 2 Practicing TOEFL PBT Section 2 Schedule

\begin{tabular}{cc}
\hline Week & Implemented Application \\
\hline 1 & Quizizz \\
2 & Socrative \\
3 & Kahoot! \\
4 & Google Form \\
5 & Quizizz \\
6 & Socrative \\
7 & Kahoot! \\
8 & Google Form \\
\hline
\end{tabular}

Table 3 Average Score of Practicing TOEFL Section 2

\begin{tabular}{ccc}
\hline \hline Week & Application & Average Score \\
\hline 1 & Quizizz & 65 \\
2 & Socrative & 62 \\
3 & Kahoot! & 64 \\
4 & Google Form & 60 \\
5 & Quizizz & 78 \\
6 & Socrative & 72 \\
7 & Kahoot! & 75 \\
8 & Google Form & 68 \\
\hline
\end{tabular}

Table 4 N-Gain Score of Each Platform

\begin{tabular}{|c|c|c|c|}
\hline Pretest Score & Posttest Application & N-Gain Score 1 & N-Gain Score 2 \\
\hline \multirow[t]{4}{*}{52} & Quizizz & 0.27 & 0.63 \\
\hline & Socrative & 0.21 & 0.48 \\
\hline & Kahoot! & 0.25 & 0.56 \\
\hline & Google Form & 0.17 & 0.38 \\
\hline
\end{tabular}

Table 5 N-Gain Category

\begin{tabular}{lcccc}
\hline Application & N-Gain Score 1 & Category & N-Gain Score 2 & Category \\
\hline Quizizz & 0.27 & least effective & 0.63 & effective \\
Socrative & 0.21 & least effective & 0.48 & less effective \\
Kahoot! & 0.25 & least effective & 0.56 & effective \\
Google Form & 0.17 & least effective & 0.38 & least effective \\
\hline
\end{tabular}

Table 4 indicated the results of the Normalized Gain score in each meeting. Each average score above was compared with the pretest using the Normalized Gain formula to determine each platform's effectiveness by looking at the N-Gain score category. Getting the Normalized Gain score for each platform in 2 meetings could be analyzed into the effectiveness of each platform based on the N-Gain score category. Table 5 revealed the category of each platform.

\section{Students' Feedback}

After finishing the drilling practice for eight weeks using multiple e-learning technologies, the participants were given an online open-ended questionnaire in Google Form regarding their comments in implementing the technologies and numbering the four e-learning technologies starting from their most favorite (number 1) into the least (number 4). The students were free to write any comments, or sharing their experience in practicing TOEFL Structure and Written Expression, implementing those 
four platforms. The questionnaire results could be defined into 2 categories, pros and cons, as shown in table 6 . Furthermore, the pros could be grouped into five kinds of feedback, while the cons were categorized into three kinds of feedback. The percentages of each category were in table $\underline{6}$ and $\underline{7}$,

Table 6 described that the multiple e-learning technologies made learning activities fun and interesting. It motivated them to learn more by themselves, which later on created autonomous learning for the students. Those four applications were also easy to be used even for those who used the applications for the first time. Some students thought this was challenging as they could compete with each other in a class by getting the winner, especially on Quizizz and Kahoot!.

It could be seen that those four applications had some problems during the implementation regarding the internet connection and the devices based on the data below. The internet connections were about the stability of the connection and the quota needed for practicing TOEFL Structure and Written Expression on each platform. As for the practicing session, the students just required their mobile phone. However, when this was for the test, they had to provide two devices, a computer or laptop and a mobile phone, for doing the test and for monitoring activity from the teacher. This also is a minor problem during the implementation of e-learning technologies. The most until the least favorite application chosen by the students outlined in Table 8 below and the bar chart of each application illustrated the data in the table provided in Figure 5 on the following. Number 1 portrayed the most favorite, number 2 and 3 were the favorite and the less favorite, while number 4 expressed the students' least favourite application.

Thus, it could be interpreted that the most favorite elearning technology used for practicing TOEFL Structure and Written Expression for Railway Mechanical Technology students was Quizizz. Almost half of the class chose that platform on number 1 (the most favorite). Those were 21 students who chose this platform which meant $43.75 \%$. Almost the same number of the students, 20 students, appointed on number 2 (the favorite application). Then the rests cast on number 3 by seven students on $14.58 \%$. The second favorite was Kahoot!, which chosen by 17 students out of 48 students in class as the most favorite. This fulfilled more than one-third of the total sample joined in this research, which was $35.42 \%$. Most of the students placed Kahoot! on number 2; those were 22 students. This was $45.83 \%$. Just a few students allowed Kahoot! on number 3, 9 students on $18.75 \%$, and there was none of them placed this application on the least favorite.

The next favorite was Socrative which ten students cast on $20.83 \%$ as the most favorite one. This was a little bit more than one-fifth of the sample, which meant that not so many students favoured this application. Moreover, more than half of the sample designated this platform on number 3 (the less favorite), 26 students. Students who opted Socrative on number 2 (favorite) and number 4 (the least favorite) were the same percentage, $12.5 \%$. This was only six students. Google Form was the least favorite application chosen by students. Besides, there were no students who chose number 1 (the most favorite) and number 2 (favorite) for this platform; there were 42 students who ticked number 4 (the least favorite) for this platform. That was $87.5 \%$ of the total sample. The rests of the students, six students $-12.5 \%$, determined number 3 for this application which also meant less favorite.

Table 6 Students' Feedback (Pros)

\begin{tabular}{lcc}
\hline \hline Students' Feedback & $\begin{array}{c}\text { Number } \\
\text { of Students }\end{array}$ & Percentage \\
\hline Fun and Interesting & 15 & $31.25 \%$ \\
Easy to be Used & 11 & $22.92 \%$ \\
Motivating for & 10 & $20.83 \%$ \\
Learning & & $16.67 \%$ \\
Helping for & 8 & \\
Autonomous & & \\
Learning & 4 & \\
Challenging and & & \\
Competitive & & \\
\hline
\end{tabular}

Table 7 Students' Feedback (Cons)

\begin{tabular}{lcc}
\hline \multicolumn{1}{c}{ Students' Feedback } & $\begin{array}{c}\text { Num } \\
\text { ber of } \\
\text { Students }\end{array}$ & Percentage \\
\hline $\begin{array}{l}\text { Need good internet } \\
\text { connection }\end{array}$ & 25 & $52.08 \%$ \\
$\begin{array}{l}\text { Need extra internet quota } \\
\text { Need two kinds of } \\
\text { devices }\end{array}$ & 18 & $37.50 \%$ \\
\end{tabular}

\section{DISCUSSION}

Due to the revolution industry 4.0, e-learning technologies are needed as a gateway in learning and teaching language (Poudel, 2015). Mastering English could be a passport for someone to enter the global world (Rokhyati, 2013). Specifically, in this pandemic era, when the teaching and learning process should be done online, teachers have to develop the skills to successfully integrate digital tools into their classroom practice (Stickler et al., 2020). Thus, technology-aided ELT (English Language Teaching) systems relied on the effectiveness and efficiency of facilitating the teaching and learning process (Mallick et al., 2020). This research has pointed out how to implement the four e-learning technologies on practicing TOEFL Structure and Written Expression for Railway Mechanical Technology students. The results of each application's effectiveness have tallied as well compared to the traditional one (paper-test practice). 
Table 8 Students' Favorite Application

\begin{tabular}{ccccccccc}
\hline \hline App & \multicolumn{1}{c}{$\begin{array}{c}2 \\
\text { Number of }\end{array}$} & $\%$ & $\begin{array}{c}\text { Number of } \\
\text { Students }\end{array}$ & $\%$ & $\begin{array}{c}\text { Number of } \\
\text { Students }\end{array}$ & \multicolumn{2}{c}{$\begin{array}{c}\text { Number } \\
\text { of Students }\end{array}$} & $\%$ \\
\hline Quizizz & 21 & 43.75 & 20 & 41.67 & 7 & 14.58 & 0 & 0 \\
Socrative & 10 & 20.83 & 6 & 12.5 & 26 & 54.17 & 6 & 12.50 \\
Kahoot! & 17 & 35.42 & 22 & 45.83 & 9 & 18.75 & 0 & 0 \\
Google Form & 0 & 0 & 0 & 0 & 6 & 12.50 & 42 & 87.5 \\
\hline
\end{tabular}

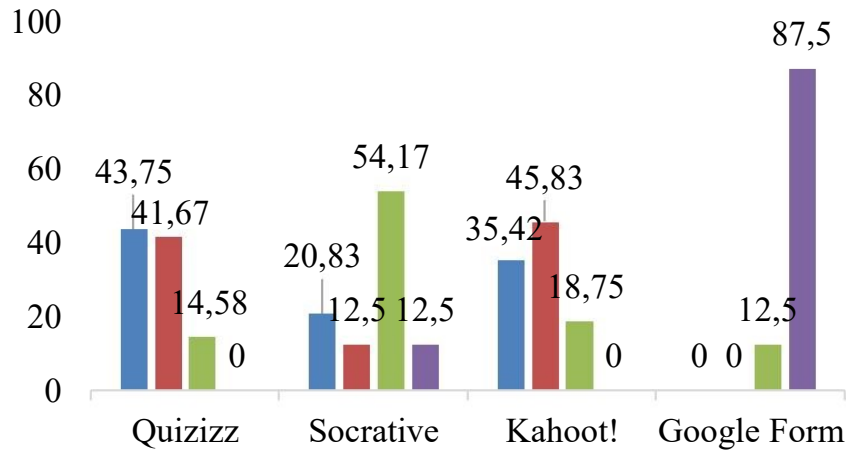

№ 1 No 2 No 3 No 4

\section{Figure 5 Chart of Students' Favorite Application}

Quizizz application enumerated as the most effective application for practicing TOEFL Structure and Written Expression and cast as the most favorite application. The findings on this study support several previous research which stated Quiziz improved students' grammar understanding while using this application (Rahayu \& Purnawarman, 2019), the higher mean score of students who taught using Quizizz compared to conventional strategy and this platform could be effectively used as a distance learning tool (Mohamad et al., 2020). Moreover, in another language classroom, this digital tool has also justified as an effective e-learning technology as long as applied not for fun but for seeking knowledge. This implied that Quizizz was the most recommended digital platform for practicing TOEFL Structure and Written Expression for Railway Mechanical

The quality and reliability of the information obtained in this study must, in theory, be assessed by quantitative analysis. Many studies have used different measures for the AMS and for the OLRS. Using the OLRS portion of this method means that the online learning experience was answered by the survey participants. The online attitude learning component is the only aspect of the data review that involves checking the validity and reliability of this report. The results of the system for analyzing data showed to classify the alpha of Cronbach $(\pi=0.87)$. Therefore, there is high reliability in the overall reliability of the online learning attitude segment. The online learning attitude instruments adjust with the validity facing achievement in Technology students of Indonesian Railway Polytechnic.

Kahoot! turned out to be the second effective yet the second favorite digital tools on practicing TOEFL Section 2. However, this platform still classified into an effective one. This study confirmed the previous study, which found out that Kahoot! expressed positive outcomes in the language class, making the student more collaborative and competitive (Basuki \&Hidayati, 2019), especially for effectively boosting the students' learning. In addition, in other language skill such as reading, this has also convinced that it was effective to improve students' score and received students' positive attitude towards its implementation neglected its advantages and disadvantages (Chiang, 2020).

Socrative, the third effective platform, was also the third favorite application chosen by the Railway Mechanical Technology program students in learning TOEFL Structure and Written Expression. This application assorted into the less effective in enhancing students' score. This finding upheld the previous research that Kahoot! is more effective than Socrative. Nonetheless, it was proven as effective multimedia in teaching grammar (Maesaroh et al., 2020). Furthermore, it could enhance students' performance (Dakka, 2015) to gain positive attitudes, which facilitated the teaching and learning process interactively in the English language classroom (Kaya \& Balta, 2016). This also confirmed as a valuable tool that promoted critical thinking and encouraged effective collaboration in the learning process (Shaban, 2017).

Google Form emerged as the least effective and the least favorite application chosen by the students. There was just a slight improvement in students' scores, and none of them ticked this application as the first or second favorite. Students Response System (SRS) such as Quizizz, Kahoot! and Socrative were more effective in increasing students' score and engagement even in a large classroom (Benson et al., 2016; Heaslip et al., 2014). This platform was a useful application that gave students and teachers ease regarding assignments' submission (Sepyanda, 2018) and a quick poll or survey (Sivakumar, 2019). Hence, the implementation of this digital tool for online examination gained varied perceptions from the students, reflecting its benefits and drawbacks. 
Students' feedback is important as in the teaching and learning process; teachers have to take into account the students' need in which interactive and communicative learning could be achieved that leads to autonomous learning. Implementing multiple e-learning technologies in practicing TOEFL Section 2 obtained several positive feedbacks from the students based on the questionnaire given. In previous research, the positive feedback in implementing e-learning technologies was obtained from the language classroom and other majors (Yoon, 2017). The students stated that those e-learning technologies were fun and interesting, which could motivate them for learning beside the easiness of using those applications. This could overcome students' lack of practice in TOEFL Section 2, one of the problems the students faced in the TOEFL preparation class (Tilana et al., 2019).

Additionally, those tools helped the students learn autonomously; indeed, autonomous learning based on an online platform was the students' favorite in learning TOEFL Structure and Written Expression (Thu, 2019) as the students could learn on what they wanted and needed. Some of the students also described that those were challenging, which created a competitive atmosphere among them. After all, familiarizing the students with TOEFL by practicing a lot through autonomous learning was an effective preparation strategy (Manoj \& Hijazi, 2018).

On the other hand, implementing e-learning technologies for practicing TOEFL Structure and Written brought several drawbacks, such as the good internet connection, more internet quota and needed at least two kinds of devices if the practice was in the form of classroom practice (not self-practicing). The problems regarding the internet were also highlighted in the previous study conducted by Azmi (2017), Maesaroh et al. (2020), Sepyanda (2018). This meant that implementing e-learning technologies needed assistance from a related party to provide a good internet connection and sufficient internet quota for students, especially during this pandemic era. Many teaching and learning processes have to be done through distance online learning, including practicing TOEFL.

\section{CONCLUSION}

This study highlighted the implementation of multiple elearning technologies (Quizizz, Kahoot!, Socrative and Google Form) in practicing TOEFL Structure and Written Expression, which broke down into the description of the effectiveness of the implementation and the students' feedback, which resulted in two aspects, the positive feedbacks and the drawbacks. The implementation of the four digital platforms has been discussed. The results reported that multiple e-learning technologies effectively improved students' scores in practicing TOEFL Structure and Written Expression, which was assumed to reflect on the TOEFL score as the more practicing created autonomous learning and higher result. The students' positive feedback could be concluded as supportive data for implementing multiple e-learning technologies, specifically TOEFL Section 2. Generally, practicing the whole TOEFL set decayed the drawbacks. So, future studies using the more advanced statistical analysis with the whole TOEFL set are recommended. The drawbacks also needed more attention from IT expert despite the related parties to support those students' problem concerning the internet connection and quota.

This study has some limitations to be acknowledged. There are only four e-learning technologies implemented in this study: Quizizz, Socrative, Kahoot!, and Google Form. There are many more digital platforms that could be used for online learning. The research type is more descriptive, supported by simple analysis using normalized gain score criteria and a short openended questionnaire to gather students' feedback. There might be different findings if other research designs, such as experimental research completed with a questionnaire or depth interview, were applied. Future studies are suggested to use experimental research designs with control and experiment class to add more discussions and perspectives.

\section{ACKNOWLEDGMENT}

I would like to thank the Indonesian Railway Polytechnic, and Railway Mechanical Technology Program team for their support during I conducted this research.

\section{REFERENCES}

Azmi, N. (2017). The Benefits of Using ICT in the EFL Classroom: From Perceived Utility to Potential Challenges. Journal of Educational and Social Research, 7(1), 111-118. https://doi.org/10.5901/jesr.2017.v7n1p111

Azmina, B., Solihah, M., \& Guritno, A. (2017). The University Students ' Perception of Online Examination Using Google Form. Britania, 1(1), 120-135. https://journal.iainkudus.ac.id/index.php/Britania/article/view/ $4318 / 2800$

Basuki, Y., \& Hidayati, Y. (2019). Kahoot! or Quizizz: the Students' Perspectives. ELLIC, April. https://doi.org/10.4108/eai.27-4-2019.2285331

Benson, J. D., Szucs, K. A., \& Taylor, M. (2016). Student Response Systems and Learning: Perceptions of the Student. Occupational Therapy in Health Care, 30(4), 406-414. https://doi.org/10.1080/07380577.2016.1222644

Budiati, B. (2017). ICT (Information and Communication Technology) Use: Kahoot Program for English Students' Learning Booster. Education and Language International Conference, 1(1), 178-188.

http://jurnal.unissula.ac.id/index.php/ELIC/article/view/1225

Chiang, H.-H. (2020). Kahoot! In an EFL Reading Class. Journal of Language Teaching and Research, 11(1), 33. https://doi.org/10.17507/jltr.1101.05

Coletta, V. P., \& Steinert, J. J. (2020). Why Normalized Gain Should Continue to be Used in Analyzing Preinstruction and Postinstruction Scores on Concept Inventories. Physical Review Physics Education Research, 16(1), 10108. https://doi.org/10.1103/PhysRevPhysEducRes.16.010108

Dakka, S. M. (2015). Using Socrative to Enhance In-Class Student Engagement and Collaboration. International Journal on 
Integrating Technology in Education, 4(3), 13-19. https://doi.org/10.5121/ijite.2015.4302

ETS. (2017). Test Taker Handbook. In Educational Testing Service. https://www.ets.org/toefl_itp/about/

Hajri, T., Jufrizal, \& Wahyuni, D. (2015). An Analysis of Difficulties in Answering Structure and Written Expression of TOEFL Made By English Students of Universitas Negeri Padang. Journal of English Language Teaching, 7(1), 93-105. https://doi.org/https://doi.org/10.24036/jelt.v7i1.8957

Heaslip, G., Donovan, P., \& Cullen, J. G. (2014). Student Response Systems and Learner Engagement in Large Classes. Active Learning in Higher Education, 15(1), 11-24. https://doi.org/10.1177/1469787413514648

Kaya, A., \& Balta, N. (2016). Taking Advantages of Technologies: Using the Socrative in English Language Teaching Classes. International Journal of Social Sciences \& Educational Studies, 2(3), 4-12. https://www.researchgate.net/publication/301495673_Ta king_Advantages_of_Technologies_Using_the_Socrativ e_in_English_Language_Teaching_Classes

Maesaroh, M., Faridi, A., \& Bharati, D. A. L. (2020). The Effectiveness of Socrative and Kahoot to Teach Grammar to Students with Different Interest. English Education Journal, 10(1), 366-373.

https://journal.unnes.ac.id/sju/index.php/eej/article/down load/36696/15228/

Mallick, P., Maniruzzaman, M., \& Das, S. (2020). Addressing Impact of Technology in English Language Teaching at Secondary Level Education in Bangladesh. International Journal of English Literature and Social Sciences, 5(3), 665-671. https://doi.org/10.22161/ijels.53.16

Manoj, S., \& Hijazi, S. (2018). Test Preparation Strategies for the TOEFL can be Diverse and Effective. International Journal of ELT, Linguistics and Comparative Literature, 6(1), 6-10.

https://www.researchgate.net/publication/326009749_Te st_preparation_strategies_for_the_TOEFL_can_be_diver se_and_effective

Mohamad, M., Arif, F. K. M., Alias, B. S., \& Yunus, M. M. (2020). Online Game-Based Formative Assessment: Distant Learners Post Graduate Students' Challenges towards Quizizz. International Journal of Scientific and Technology Research, 9(4), 994-1000.

http://www.ijstr.org/final-print/apr2020/Online-Gamebased-Formative-Assessment-Distant-Learners-PostGraduate-Students-Positive-Perceptions-TowardsQuizizz.pdf

Mohammed, A.-K., \& Chouthaiwale, D. S. S. (2018). The Use of ICT Tools in English Language Teaching and Learning: A Literature Review. Journal of English Language and Literature, 5(January 2018), 0-5. https://www.researchgate.net/publication/330986788

Mufidah, N. (2012). English Language Learners' Mastery in TOEFL Structure-Written Expression (A Case Study at IAIN Antasari, UNLAM, UNISKA and STKIP PGRI in South Kalimantan). LET (Linguistic Literature English Teaching) Journal, 2(2). http://jurnal.uinantasari.ac.id/index.php/let/article/view/1378/996
Poudel, P. P. (2015). Information and Communication Technologies and Teacher Educators of English in Nepal. Journal of NELTA, 20(1-2), 27-33. https://doi.org/10.3126/nelta.v20i12.19774

Pratiwi, D. I., Faridi, A., \& Hartono, R. (2016). The Implementation of Mind Mapping Strategy to Teach Writing in IELTS Preparation Class. Lembaran Ilmu Kependidikan, 45(1), 3341.

https://journal.unnes.ac.id/nju/index.php/LIK/article/view/764 $0 / 5330$

Rahayu, I. S. D., \& Purnawarman, P. (2019). The Use of Quizizz in Improving Students' Grammar Understanding through SelfAssessment. Advances in Social Science, Education and Humanities Research, 254(11), 102-106. https://doi.org/10.2991/conaplin-18.2019.235

Rahmawati, L. E., Suwandi, S., Saddhono, K., \& Setiawan, B. (2019). Construction of Test Instrument to Assess Foreign Student's Competence of Indonesian Language through Objective Test. International Journal of Instruction, 12(4), 35-48. https://doi.org/10.29333/iji.2019.1243a

Rokhyati, U. (2013). Teaching English at Higher Education in Indonesia: Searching For Usefulness. SELT 2013 Proceeding, $1-11$.

http://ejournal.unp.ac.id/index.php/selt/article/download/6793 15332

Sariani, S., Yaningsih, Y., \& El Khairat, M. (2020). Assessing the Effectiveness of Mobile-Application Technology: A ProjectBased Learning. JEES (Journal of English Educators Society), 5(1), 67-73. https://doi.org/10.21070/jees.v5i1.376

Sepyanda, M. (2018). Students' Attitude Toward the Use of Google Classroom on Translation Subject in English Department of FKIP UMMY Solok. English Language Teaching and Research, 2(1), 180-188. http://ejournal.unp.ac.id/index.php/eltar/article/view/102661

Shaban, A. El. (2017). The use of Socrative in ESL Classrooms: Towards active learning. Teaching English with Technology, 17(4), 64-77.

Sivakumar, R. (2019). Google Forms in Education. Journal of Contemporary Educational Research and Innovations ( JCERI ), 9(1).

Stickler, U., Hampel, R., \& Emke, M. (2020). A Developmental Framework for Online Language Teaching Skills. Australian Journal of Applied Linguistics, 3(1), 133-151. https://doi.org/10.29140/ajal.v3n1.271

Thu, A. S. (2019). Autonomous Learning Materials of Structure and Written Expression for TOEFL Preparation. LingTera, 6(1), 62-72. https://doi.org/10.21831/lt.v6i1.15919

Tilana, P. E., Yunita, W., \& Zahrida. (2019). Students' English Structure and Written Competence. Journal of English Education and Teaching, 322(2), 180-194. https://ejournal.unib.ac.id/index.php/JEET/article/view/8652/ 4157

Ubaedillah, U., Pratiwi, D. I., Mukson, Masrikhiyah, R., \& Nurpratiwiningsih, L. (2020). Pelatihan Wawancara Kerja dalam Bahasa Inggris bagi Siswa SMK Menggunakan Metode Demonstrasi. JAMU : Jurnal Abdi Masyarakat UMUS, 1(1). http://jurnal.umus.ac.id/index.php/jamu/article/view/317 Waluyo, B. (2020). Learning Outcomes of a General English Course Implementing Multiple E-Learning Technologies and Active Learning Concepts. The Journal of AsiaTEFL, 17(1), 
$160-181$.

https://doi.org/10.18823/asiatefl.2020.17.1.10.160

Wong, A. (2016). Student Perception on a Student Response System Formed by Combining Mobile Phone and a Polling Website. International Journal of Education \& Development Using Information \& Communication Technology, 12(1), 144-153.

http://ezproxy.swu.edu:2048/login?url=http://search.ebsc ohost.com/login.aspx?direct=true $\& d b=e f t \& A N=115161$ 963\&site $=$ eds-live

Yanmei, S., YanJu, S., \& Adam, Z. (2018). Implementing Quizizz as Game-Based Learning in the Arabic Classroom. European Journal of Social Sciences Education and Research, 12(1), 208. https://doi.org/10.26417/ejser.v12i1.p208-212
Yoon, S. Y. (2017). Using Learner Response Systems in EFL Classrooms : Students' Perspective and Experience. Multimedia-Assisted Language Learning, 20(2), 36-58. https://www.researchgate.net/publication/318107506 Using_Learner_Response_Systems_in_EFL_Classroo ms_Students'_Perspectives_and_Experience

ConflictofInterestStatement:Theauthorsdeclarethattheresearchwasconducted in the absence of any commercial or financial relationships that could be construed as a potential conflict ofinterest.

Copyright (C) 2021 Damar Isti Pratiwi, Dadang Sanjaya Atmaja, Henry Widya Prasetya. This is an open-access article distributed under the terms of the Creative Commons Attribution License (CC BY). The use, distribution or reproduction in other forums is permitted, provided the original author(s) and the copyright owner(s) are credited and that the original publication in this journal is cited, in accordance with accepted academic practice. No use, distribution or reproduction is permittedwhichdoesnotcomplywiththese terms. 